\title{
Students View Towards Religion-based Terrorism: A Study on Hajee Mohammad Danesh Science and Technology University (HSTU), Dinajpur, Bangladesh
}

\author{
Md Abdur Rashid ${ }^{1, *}$, Mohammad Saifuddin Durud ${ }^{1}$, A.S.M. Mahbubur Rahman², \\ Sabrina Mustafiz ${ }^{1}$, Md. Noman Amin ${ }^{3}$

\begin{abstract}
${ }^{1}$ Department of Sociology, Hajee Mohammad Danesh Science and Technology University, Dinajpur, Bangladesh
${ }^{2}$ Department of English, Hajee Mohammad Danesh Science and Technology University, Dinajpur, Bangladesh

${ }^{3}$ Department of Sociology, Bangabandhu Sheikh Mujibur Rahman Science and Technology University, Gopalganj, Bangladesh

*Corresponding author: rashidm@unbc.ca
\end{abstract}

Received June 18, 2018; Revised August 06, 2018; Accepted August 24, 2018

\begin{abstract}
Terrorism has now become a global issue. In the last couple of years, Bangladesh has already been faced different terrorist attacks for which the peace and harmony of the society become disrupted. Investigation after the occurrence of terrorist activities revealed that mostly students are being engaged with such kind of activities in Bangladesh. Among them mostly university students are being engaged with it. In a situation, knowing students view regarding terrorism has become a sociological issue for the country. This study is conducted among the students of HSTU. Data has been collected through surveying 90 students from different departments along with interviewing 20 students who are being selected purposively. Students have been asked several questions regarding the issues of terrorism. Students strongly opposed the modern version of religious terrorism in the name of religious goal attainment. They treated it as a threat to their student life as well as to the society and state. They suggested that building strong connection between parents and children, creating social and societal awareness, spreading religionbased education system, constructing strong constitutional provision against terrorist activities and developing the sense of multiculturalism etc. would contribute in combating such kind of terrorist activities.
\end{abstract}

Keywords: Terrorism, religion-based terrorism, terrorism and students view

Cite This Article: Md Abdur Rashid, Mohammad Saifuddin Durud, A.S.M. Mahbubur Rahman, Sabrina Mustafiz, and Md. Noman Amin, "Students View Towards Religion-based Terrorism: A Study on Hajee Mohammad Danesh Science and Technology University (HSTU), Dinajpur, Bangladesh." American Journal of Educational Research, vol. 6, no. 8 (2018): 1233-1237. doi: 10.12691/education-6-8-24.

\section{Introduction}

Following the last two decades, Bangladesh has experienced several terrorist attacks that manifested the existence of terrorist group within its geographical boundaries. Terrorism has become a means of threat to life, socio-economic structure and political order of the country. The religion-based terrorist groups organize such type of activities with the intention of establishing religious order in the society [1].

There are different organizations who support terrorist activities in Bangladesh. They are intended to establish Bangladesh as an Islamic country by the means of militant power as an execution of religious spirit according to their own perception. Some of such organizations are Jagrato Muslim Janata Bangladesh (JMJB), Jamatul Mujahideen Bangladesh (JMB), Harkat-ul-Jihad-al Islami Bangladesh (HuJI-B) and so on [2].

Very recently Bangladesh has witnessed different terrorist attacks within its boundary that is acknowledged by the world's largest terrorist group ISIS in their magazine named 'Dabiq'. They are committed to attack on foreigners, Ahmadis, Sufis, homosexuals, Shia, and other religious minorities, among other groups. They also operated attacks against the secular writers, bloggers, intellectuals and so other targeting groups [2].

At present, it is a burning question that why terrorism is spreading rapidly in Bangladesh. To deal with this alarming issue, actual causes behind terrorism need to be identified [3]. The terrorist organizations of the present era become organized with a new way like digital media campaign where mostly young people are getting influenced by them. They influence young people specially students from different higher educational institutions by demonstrating astounding cases operated against their religious community happening around the world [4]. Students who have lack of proper religious knowledge are mostly being influenced by them. Specially they are being targeted as it is easy to convert them according to their own ways by the means of so called religious spirit and simulation.

Nowadays terrorism has become a serious threatening issue to the national security of Bangladesh [1]. The main 
aim of this research is to create awareness among the university students. As the major findings, the study explores the students' view towards religion-based terrorism. The study also conveys the messages of how to get rid of this problem.

\section{Scenario of Terrorism: Worldwide and Bangladesh}

Terrorism spreads in a locality that engulfs the harmony of the society silently and brings immature death of democracy [5]. If religious extremism at any level exist in a society it is not possible to keep the peace and harmony of that particular society [6]. Everyone can be considered as a terrorist unless he obeys the ways of humanity and consider himself as a human being who wouldn't hamper any human being in an inhuman procedure [7]. Terrorist activities are occurring in our surroundings and all over the world due to the absence of moral education which should be practiced at family [8]. In many cases the negligence of state in preventing terrorism in the comprehensive ways is liable for the continuous increment of religious extremism that finally destroys the harmony and peace of the society [9].

Historical incident indicates that terrorism is a byproduct of a group of deviated people of a given society who desperately seek harmful ways to destroy the harmony of the society. They are intended to derive on such a path as they find all other peaceful means as ineffective. They hit upon the existing social order to establish their rules according to their own way without considering the interest of the majorities. "The way Hitler and Mussolini succeeded in capturing power through terror, eventually with mass support, should be an eyeopener for both the ruling parties and their oppositions" [10].

Nowadays most of the developed and developing countries experienced some forms of terrorist attack that aware their authorities to be more conscious about their safety. Security has become the first priority to EU, USA, UK, France, Germany etc. and these all are fighting against terrorism [11].

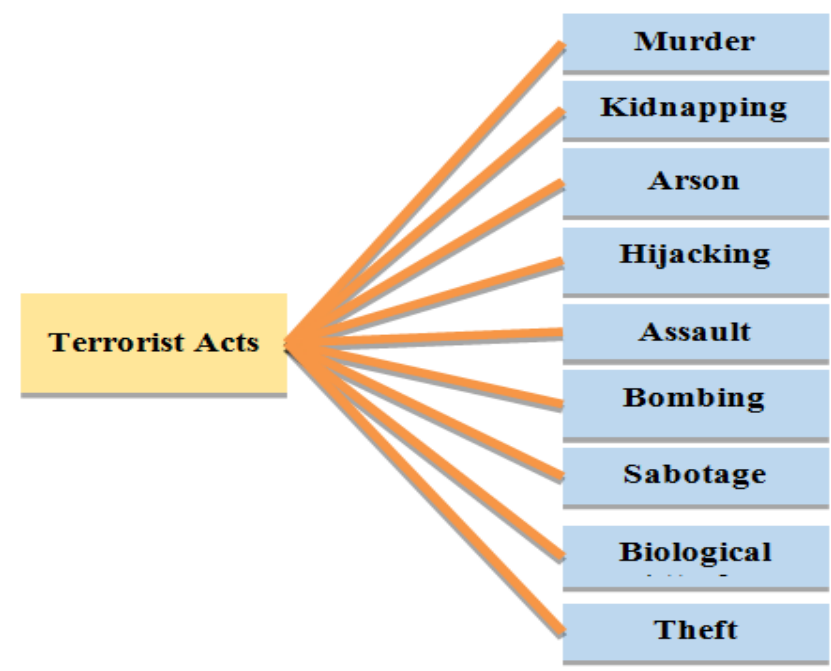

Figure 1. Forms of terrorist activities followed in different countries [12]
The JMB operated several attacks in Bangladesh since the beginning of $21^{\text {st }}$ century, notably the bomb blasting during 2005 around the whole country when about 450 bombs were set off and blasted simultaneously in 63 districts of the country. Their intention was to adopt sharia laws in Bangladesh by the means of illegal human killing that is not permitted by Islam. They are continuously engaged in such kind of terrorist activities including recent incident occurred in Dinajpur at the end of 2015 where an Italian Catholic priest was targeted for killing. Another terrorist group named Harkat-ul-Jihad-al Islami Bangladesh (HuJI-B) also responsible for conducting such type of terrorist activities. They are intended to assassin secularist writer and intellectuals who expose their opinions through their writings. Among their target, the secularist poet Shamsur Rahman and Prime Minister Sheikh Hasina are notably included [2].

The ISIS generated magazine named 'Dabiq' acknowledged most of them as Jihadist group in Bangladesh who act to establish religion-based Sharia laws through the means of terrorism. It argued that most of them have trained from Afghanistan and are came back to this country after the end of 'Jihad against communist party' in Afghanistan [13]. It mentioned most of the political parties in Bangladesh as secularist and through them under target killing. According to the magazine, the terrorist activities that followed by the popular terrorist named 'Shaykh Abdur-Rahmān' during the last decade of 20th century became ineffective after revealing their appearance and governmental action against them. Besides they are being "fragmented through disputes over issues of creed, methodology, leadership, strategy, and tactics". Recently they are being reiterated after the declaration of Khilafah followed in the land of Syria in 2015 [13].

\section{Significance of the Research}

The main focus of this research is to find out the effects of religion-based terrorism on the students of Bangladesh and how it adversely affects them. Universities have drawn sincere concern as students have become easy victims of religion-based terrorist groups. The ultimate result of this research will assist to discover the opinions and attitudes of the students of HSTU towards religion and religion-based terrorism. If we able to find out how the students respond towards terrorist activities, it might be a trustworthy guide for other universities. Students of different universities are directly connected with these attacks whose brains are washed by religion-based terrorist groups like ISIS and other terrorist groups. This research will assist to identify the views of the students of HSTU and might raise their consciousness about staying away from religion-based terrorist groups and activities.

\section{Research Objectives:}

- To find out the students view regarding recent terrorist activities in Bangladesh and across the world.

- To explore the probable reasons behind the ongoing terrorist activities. 
- To identify the effective measures to combat religion-based terrorism.

\section{Methodology}

Hajee Mohammad Danesh Science and Technology University is now one of the leading public universities that has more than 10000 students with a large campus of 130 acres. The students of HSTU have observed recent terrorist attacks in our country and worldwide which strongly affects their tender minds. The university consists of 43 departments under nine faculties offering 19 degrees [14]. This study followed mixed methodology where survey research design has been implemented for gathering quantitative data and interview research design has been implemented for gathering qualitative data. Due to time and monetary limitation, a group of 90 students from different departments has been purposively selected for questionnaire survey. A structured questionnaire has been developed consisting both close-ended and openended questions for collecting survey data. 20 students from different departments have been taken for interviewing. For analyzing survey data, SPSS (Statistical Package for Social Science) has been used. Quantitative data has been generated in the form of table and graphs. Relevant qualitative data has been attached along with the quantitative data.

\section{Results}

Table 1. Respondents' status of familiarity with the term of terrorism.

\begin{tabular}{|l|l|l|l|}
\hline & Frequency & Percent & Cumulative Percent \\
\hline Yes & 90 & 100.0 & 100.0 \\
\hline No & 0 & 0.0 & \\
\hline
\end{tabular}

In this study all of the respondents know about the meaning of the term of terrorism. Among them $28.9 \%$ learned about it from newspaper, $47.8 \%$ from television, $3.3 \%$ from friend circle and remain $20 \%$ from the internet.

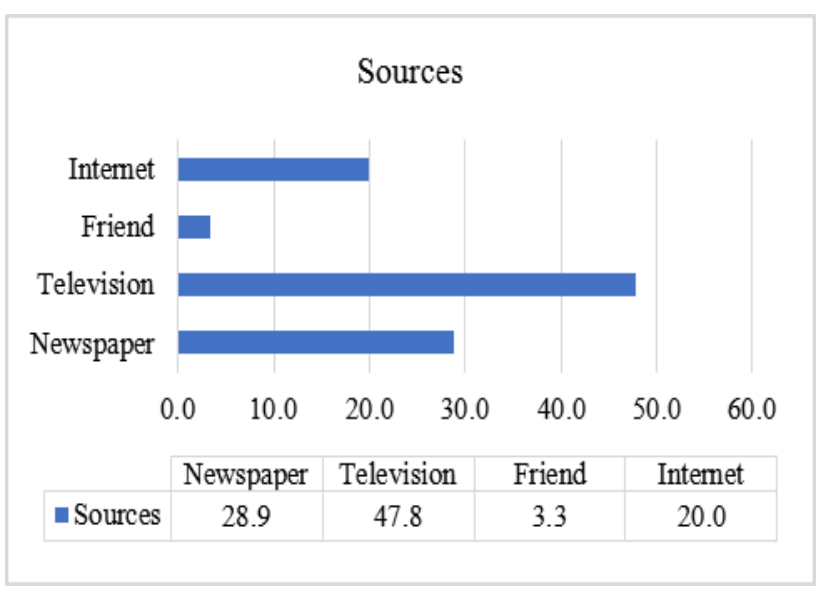

Figure 2. Sources of getting informed about terrorism

Terrorism in the view of $86.7 \%$ respondents is seen as a big problem, $4.4 \%$ are worrying a little bit and $8.9 \%$ expresses no comments regarding this.
Table 2. Views about terrorism

\begin{tabular}{|l|l|l|l|}
\hline & Frequency & Percent & Cumulative Percent \\
\hline Big Problem & 78 & 86.7 & 86.7 \\
\hline A little bit worrying & 4 & 4.4 & 91.1 \\
\hline No comments & 8 & 8.9 & 100.0 \\
\hline Total & 90 & 100.0 & \\
\hline
\end{tabular}

This study also showed that students are concerned about the recent terrorists' incident of Holy Artisan where about 24\% respondents are concerned mostly, 53.3\% slightly and $22.2 \%$ are not aware about this.

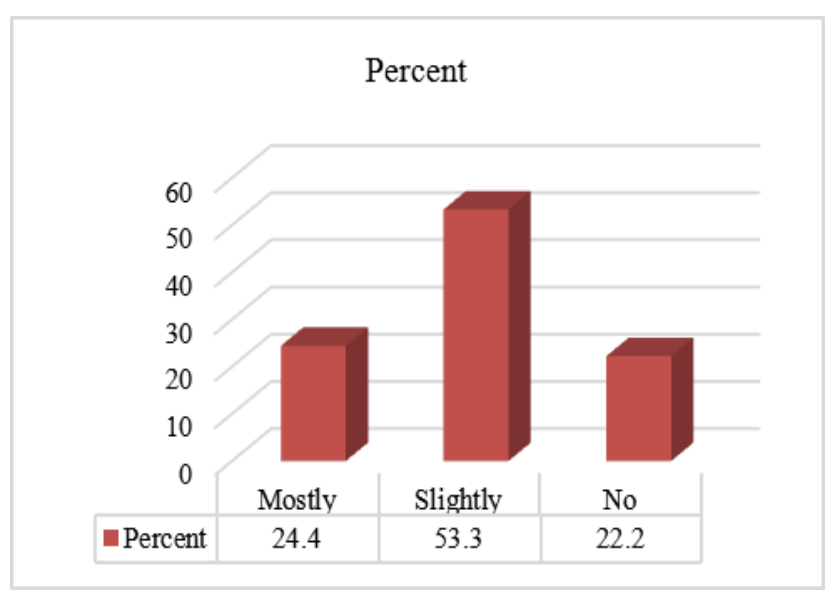

Figure 3. Concerned about Holy Artisan terrorist attack

About $22 \%$ respondents think that terrorism is extremely a threat for student life while $55.6 \%$ think it as slightly and $13.3 \%$ see it as nothing for them.
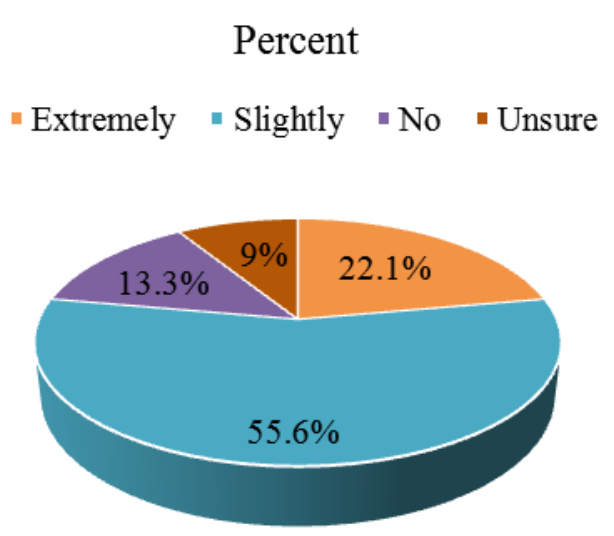

Figure 4. Terrorism as a threat of student life

About 58\% respondents opined that community-based awareness should be developed for controlling terrorism where $41.1 \%$ respondents opined it is not an effective measure to combat it.

Table 3. Terrorism and community awareness.

\begin{tabular}{|l|l|l|l|}
\hline & Frequency & Percent & Cumulative Percent \\
\hline No & 37 & 41.1 & 41.1 \\
\hline Yes & 53 & 58.9 & 100.0 \\
\hline Total & 90 & 100.0 & \\
\hline
\end{tabular}


$38.9 \%$ respondents thought that special thinking is needed against terrorism where about $61 \%$ respondents opined that it is not needed.

Table 4. Terrorism and special thinking

\begin{tabular}{|l|l|l|l|}
\hline & Frequency & Percent & Cumulative Percent \\
\hline No & 55 & 61.1 & 61.1 \\
\hline Yes & 35 & 38.9 & 100.0 \\
\hline Total & 90 & 100.0 & \\
\hline
\end{tabular}

Respondents opined that family, social and societal awareness should be developed to combat religion-based terrorism. Most of them opined that a strong provision of governmental action should be taken in reducing the vast flow of terrorist activities around the country. Some of them opined that anti-terrorism-based campaign can be organized in different educational institutions to increase awareness among the students: "Anti-terrorism campaign should organize in different educational institutions where students can learn about religious values, religion, bad effects of terrorist attack and so on" (respondent from Agriculture Department, male).

According to them, parents should be more active in monitoring child behavior as where are they going, to whom they are interacting as well as should observe all of their activities. A respondent stated it as: "Parent should be more care about their children. They should monitor their activities, review peer group to whom they are going through, teach them proper religious guideline from the childhood and above all control their behavior" (respondent from Architecture Department, male).

A sense of multiculturalism should be developed where people can make judgement of other in accordance of them rather of their own justification. Everyone should respect other religion. "Education is a primary solution to terrorism. The government should educate the people to understand the differences in culture, religion, belief and human behavior. All people should think of freedom, peace and harmony. People should obey others based on judging their perception by their values not by himself" (respondent from Sociology Department, male).

A significant number of the respondents opined that education is a primary solution to combat religion-based terrorism. As like as other causes, illiteracy is responsible for terrorist activities. In this regard religion-based education system should provide where students can learn proper lesson of religion. "People should be given proper religious knowledge from their childhood. Their family should maintain proper connection with religious rituals" (respondent from English Department, male). Another respondent opined that: "It should be observed from which sources people are getting their knowledges. People must learn religion from a religious leader not from unauthentic sources" (respondent from EEE Department, female).

In this way students as well as people can get away from terrorist activities generated from the misinterpretation of religious doctrine. Besides accurate religious practice should be developed among the people: "People should properly follow their religion and understand religion by original religious manuscript not guided by misleading people" (a respondent from CSE Department, male).
Other respondents mentioned that proper administrative management, monitoring peer group, developing honesty among the political parties can be considered in combating religion-based terrorism. Broadcasting anti-terrorism-based campaign in electronic media can also be an effective measure in combating religion-based terrorism: "Print and electronic media should engage in providing proper information about terrorism, its causes and harmful effects for society" (respondent from Fisheries Department, female).

In the university level, university administration should be concerned regarding the issue and monitor students' behavior. Despite the above preventive measure some of the respondents mentioned that state defensive bodies should be active against any appearance of terrorist activities. International bodies should work with each other to combat terrorist activities.

Table 5. Influenced by misinterpretation of religious quote

\begin{tabular}{|l|l|l|l|}
\hline & Frequency & Percent & Cumulative Percent \\
\hline No & 90 & 100.0 & 100.0 \\
\hline Yes & 0 & 0.0 & \\
\hline Total & 90 & 100.0 & \\
\hline
\end{tabular}

In this university, significantly all of the respondents expressed that they are not being influenced by the misinterpretation of religious quote or deviated person who are being influenced by it.

Table 6. HSTU environment assist religion-based terrorism

\begin{tabular}{|l|l|l|l|}
\hline & Frequency & Percent & Cumulative Percent \\
\hline No & 90 & 100.0 & 100.0 \\
\hline Yes & 0 & 0.0 & \\
\hline Total & 90 & 100.0 & \\
\hline
\end{tabular}

In a question whether HSTU environment assist religion-based terrorism or not, $100 \%$ respondents answered that 'no', it is not. In the following figure, it is revealed that $11 \%$ respondents argued that family is responsible for a person of being involved with such terrorist activities where $28 \%, 39 \%$ and $22 \%$ respondents opined that peer group, environment and other factors are responsible for the involvement of such kind of activities respectively.

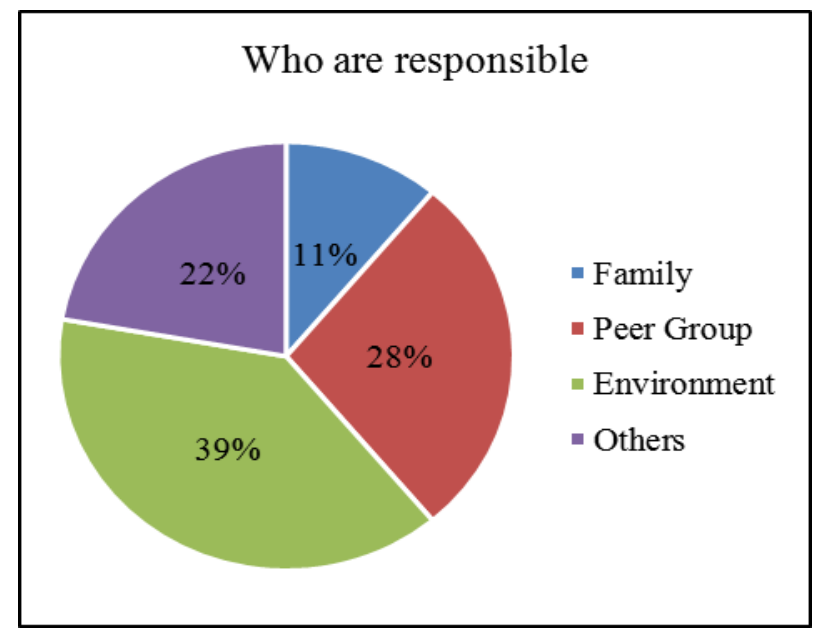

Figure 5. Opinions about who are responsible by such kind of terrorist activities 
In an open-ended question, respondents opined that rival political group, illiteracy, existing social system, global and national politics and activities of perverted person are responsible for increasing terrorist activities.

\section{Discussion}

This study is conducted among the students of HSTU. Recently we have witnessed various terrorist attacks in Bangladesh that are followed by young people and mostly by the university students. This study aims to uncover the views of HSTU students towards terrorism. In this study, all of the respondents have a little bit knowledge about the term of terrorism, its effects, recent incidents and so other issues related with terrorism. In this information and communication age, most of the students informed it from internet, newspaper and television $(96.7 \%)$ where a few numbers of them have informed it from their friends. Unlike supporting it, $86.7 \%$ of the students saw it as a big problem for our society, about $4 \%$ students are a little bit worried and $8.9 \%$ of them expressed no comments regarding this.

In the eye of students, terrorism is seen as a threat for students' life, while majority of them expressed slight concern about it for the student life. In this study, most of the students $(77.8 \%)$ are extremely or slightly concerned about the recent incident of Holy Artisan terrorist attack.

Regarding the recent terrorist incidents in Bangladesh, most of the respondents $(58.9 \%)$ think that community awareness should be developed for combating terrorism while in a later question about $38 \%$ respondents think that special thinking i.e., other measures should be developed rather community awareness in combating terrorist activities.

We asked them to know whether they are getting influenced by any misinterpretation of religious quote or not. All of the respondents ensured that they are not being influenced by such misinterpretation. Surrounding environment often pulled or pushed its member towards an activity. In the case of terrorism this scenario is true for the student as recent terrorist investigation revealed and suggested. In the view of the students, all of the respondents opined that HSTU environment does not support terrorism motivated activities. Observing some recent terrorist incidents and terrorist groups, $11 \%$ respondents opined that family is responsible for a person of being involved in terrorist activities, $28 \%$ of them think that peer group is responsible for getting involved in terrorist activities, where $22 \%$ of them opined that other factors such as psychological disorder, monetary influence etc. are responsible for engaging with such activities.

\section{Conclusion}

Terrorism is a great challenge and problem for our society. As like the global flow, the terrorist incidents, activities and trends are not different in Bangladesh. As different reports suggest that students are mostly engaged with such activities, if a proper initiative is not being proceed against such kind of activities, Bangladesh as a terrorist sanctuary will not be a surprising issue in near future. Educating proper religious knowledge to its citizen, practicing religious rituals at the core level, increasing parents' connection with children, monitoring peer group and online based activities, and anti-terrorism campaign may contribute in combating religion-based terrorism.

\section{References}

[1] Sohel, S. Terrorism in Bangladesh. Presentation presented at; 2010.

[2] Fair, C. C, Political Islam and Islamist Terrorism in Bangladesh: What You Need to Know. Lawfare.

https://www.lawfareblog.com/political-islam-and-islamistterrorism-bangladesh-what-you-need-know. Published 2018. Accessed July 15, 2018.

[3] Bashar, I. (2017). Countering Violent Extremism in Bangladesh. Counter Terrorist Trends and Analyses, 9(6), 17-21. Retrieved from http://www.jstor.org/stable/26351528

[4] Roser, M, Nagdy M, Ritchie H. Terrorism [Internet]. Our World in Data. 2018 [cited 4 August 2018]. Available from: https://ourworldindata.org/terrorism

[5] Hoffman, B, Inside Terrorism. Columbia University Press; 2006.

[6] Kressel, N, Bad Faith: The Danger of Religious Extremism. Amherst, N.Y.: Prometheus Books; 2007.

[7] Martin, G., Understanding terrorism: Challenges, perspectives, and issues. Thousand Oaks, CA, US: Sage Publications, Inc. 2006.

[8] Khosrokhavar, F., Macey D. Suicide Bombers: Allah's New Martyrs. Pluto Press; 2005.

[9] Bjørgo, T., Root Causes of Terrorism. London: Routledge; 2005.

[10] Hashmi T. Terrorism and the Divisive Polity of Bangladesh [Internet]. Mm-gold.azureedge.net. 2018 [cited 4 August 2018]. Available from:

https://mmgold.azureedge.net/Articles/taj_hashmi/terrorism_divisive_policy. html.

[11] Horgan, J., The Psychology of Terrorism. London: Routledge; 2014.

[12] Desai, R., TERRORISM - Dr Rajiv Desai [Internet]. Drrajivdesaimd.com. 2018 [cited 15 July 2018]. Available from: http://drrajivdesaimd.com/2013/06/01/terrorism/.

[13] The Revival of Jihād in Bengal. Dabiq. 2018; (12): 37-41.

[14] https://www.hstu.ac.bd. 